\title{
Pengaruh Model Pembelajaran Kooperatif Tipe Make a Match Terhadap Hasil Belajar Matematika
}

\author{
Nana Harlina Haruna ${ }^{1}$, Muhdaniar Darwis ${ }^{2}$ \\ ${ }^{1,2}$ Universitas Sawerigading Makassar \\ 1nanaharlina86@gmail.com \\ ${ }^{2}$ muhdaniardarwis1985@gmail.com
}

\begin{abstract}
ABSTRAK
Tujuan Penelitian ini adalah menelaah Pengaruh Model Pembelajaran Kooperatif Tipe Make A Match Terhadap Hasil Belajar Matematika. Pendekatan yang digunakan adalah Pre Experimental Design dengan tipe One-Shot Case Study dimana peneliti hanya mengadakan treatment satu kali yang diperkirakan sudah mempunyai pengaruh. Kemudian diadakan post test. Populasi dalam penelitian adalah seluruh siswa SDN 149 Tungke dengan sampel kelas VA sebagai Kelas Eksperimen dan VB sebagai Kelas Kontrol. Teknik analisis data terdiri dari Uji Normalitas, Uji Homogenitas dan Uji Hipotesis. Hasil penelitian menunjukkan bahwa: Penggunaan Model Pembelajaran Kooperatif Tipe Make A Match pada mata pelajaran matematika memberikan pengaruh positif terhadap peningkatan hasil belajar siswa yang meningkat sehingga memberikan pengaruh yang signifikan.
\end{abstract}

Kata kunci: Model Pembelajaran Kooperatif, Tipe Make A Match,Hasil Belajar

\section{ABSTRACT}

The purpose of this study was to determine the effect of Make A Match Cooperative Learning Model on Mathematics Learning Outcomes. The approach used is the Pre Experimental Design with the type of One-Shot Case Study where the researcher only carries out one treatment that is considered influential. Then the post test was held. The population in this study were all students of SDN 149 Tungke with a sample class VA as the Experiment Class and VB as the Control Class. The data analysis technique consisted of Normality Test, Homogeneity Test and Hypothesis Test. The results showed that: The use of the Make A Match type of cooperative learning model in mathematics has a positive effect on improving student learning outcomes which increases so that it has a significant effect.

Keywords: Cooperative Learning Model, Type Make A Match, Learning Outcomes.

\section{PENDAHULUAN}

Dalam kehidupan sehari-hari, siswa memiliki perbedaan dalam hal kemampuan intelektual, kemampuan fisik, latar belakang keluarga, kebiasaan dan pendekatan belajar yang terkadang sangat mencolok antara seorang siswa dengan siswa lainnya. Penyelenggaraan pendidikan di sekolahsekolah pada umumnya hanya ditujukan kepada para siswa yang berkemampuan rata-rata, sehingga siswa yang berkemampuan lebih atau berkemampuan kurang terabaikan. Dengan demikian, siswa yang berkategori di luar rata-rata itu tidak mendapat kesempatan yang memadai untuk berkembang sesuai dengan kapasitasnya. Dari hal inilah kemudian timbul kesulitan belajar.
Salah satu cara mengatasi kesulitan belajar ini adalah dengan menciptakan inovasi-inovasi baru yang dilakukan dan digunakan para guru dalam proses pengajaran. Salah satu aspek yang mempengaruhi proses belajar mengajar adalah model pembelajaran yang sesuai.

Guru dapat menciptakan inovasi mengajar dengan model pembelajaran yang bervariasi. Model mengajar merupakan suatu jalan atau cara dalam pembelajaran. Agar siswa dapat menerima, menguasai, dan selalu mengingat materi pelajaran, maka cara mengajar guru harus efektif dan efisien.

Dalam proses belajar mengajar di sekolah, model pembelajaran yang digunakan guru merupakan salah satu 
faktor dari luar diri siswa yang dapat mempengaruhi prestasi belajar siswa. Penggunaan pendekatan pembelajaran yang cenderung membuat siswa pasif dalam proses belajar mengajar, dapat membuat siswa merasa bosan sehingga tidak tertarik lagi untuk mengikuti pelajaran tersebut, terlebih lagi pelajaran matematika berkaitan dengan konsep-konsep abstrak, sehingga pemahamannya membutuhkan daya nalar yang tinggi. Oleh karena itu, dibutuhkan ketekunan, keuletan, perhatian, dan motivasi yang tinggi untuk memahami materi pelajaran matematika.

Permasalahan dalam proses belajar mengajar juga terjadi di SD Negeri 149 Tungke Kabupaten Bone. Sebagaimana hasil wawancara peneliti dengan guru Kelas V di sekolah tersebut bahwa pada umumnya proses pembelajaran yang digunakan adalah dengan menggunakan model pembelajaran konvensional yakni ceramah, tanya jawab, pemberian tugas dan pembelajarannya didominasi oleh guru dan sedikit sekali melibatkan siswa.

Pada pembelajaran matematika, guru kurang memberikan peluang kepada siswa untuk mengkonstruksi sendiri konsep-konsep matematika, siswa hanya menyalin apa yang dikerjakan oleh guru. Selain itu siswa tidak diberikan kesempatan untuk mengemukakan ide dan mengkonstruksi sendiri dalam menjawab soal latihan yang diberikan oleh guru.

Salah satu model pembelajaran yang dapat digunakan pada mata pelajaran Matematika adalah model pembelajaran kooperatif atau cooperative learning. Pembelajaran kooperatif merujuk pada berbagai macam metode pengajaran di mana para siswa bekerja dalam kelompokkelompok kecil untuk saling membantu sama lainnya dalam mempelajari materi pelajaran. Model pembelajaran kooperatif merupakan teknik pengelompokkan yang di dalamnya siswa bekerja terarah pada tujuan belajar bersama dalam kelompok kecil yang umumnya terdiri dari 4-5 orang.

Pembelajaran kooperatif tipe make a match dapat menjadi salah satu upaya pembelajaran pada mata pelajaran Matematika. Tipe make a match atau mencari pasangan dikembangkan oleh Lorn Curran. Keunggulan make a match adalah siswa mencari pasangan sambil belajar mengenai topik dalam suasana yang menyenangkan.

\section{Hasil Belajar Matematika}

Hasil belajar

merupakan

kemampuan-kemampuan yang dimiliki siswa setelah ia menerima pengalaman belajarnya. Gagne membagi hasil belajar menjadi lima kategori, yaitu informasi verbal, keterampilan intelektual, strategi kognitif, sikap, dan keterampilan motoris. Menurut Bloom, hasil belajar mencakup kemampuan kognitif, afektif, dan psikomotorik.

Hasil Belajar Matematika adalah ukuran kemampuan siswa atau nilai yang diperoleh siswa sebagai gambaran atas hasil usaha yang dicapai dalam proses pembelajaran matematika yang dapat diketahui melalui tes yang diberikan.

Hasil belajar dapat dinyatakan dari berbagai bentuk: (1) Keterampilan sebagai hasil belajar; (2) Himpunan tanggapan sebagai pernyataan hasil belajar; (3) Sikap dan rujukan nilai sebagai pernyataan hasil belajar; (4) Kecakapan menyelesaikan masalah; (5) Pengetahuan sikap; (6) Keterampilan menggunakan metode baru.

\section{Model Pembelajaran Kooperatif}

Pembelajaran kooperatif adalah bagian dari sebuah perubahan paradigma yang lebih luas yang terjadi dalam bidang pengajaran. Pembelajaran kooperatif adalah pembelajaran yang secara sadar menciptakan interaksi yang silih asah sehingga sumber belajar bagi siswa bukan hanya guru dan buku ajar, tetapi juga teman sesama siswa.

Pembelajaran kooperatif adalah pembelajaran yang di dalamnya mengkondisikan para siswa untuk bekerja bersama-sama di dalam kelompokkelompok kecil untuk membantu satu sama lain dalam belajar.

\section{Tipe Make A Match}

Tipe mencari dan membuat pasangan (make a match) dikembangkan oleh Lorna Curran pada tahun 1994. Tipe make a match ini adalah metode pembelajaran yang mengajak siswa mencari jawaban terhadap 
suatu pertanyaan atau pasangan dari suatu konsep melalui suatu permainan kartu pasangan.

Penerapan metode ini dimulai dengan teknik, yaitu guru menyuruh siswa mencari pasangan kartu yang merupakan jawaban atau soal sebelum batas waktunya, siswa yang mencocokkan kartunya diberi poin.

Tipe make a match atau mencari pasangan ini dapat menjadi salah satu tipe pembelajaran kooperatif yang dapat digunakan guru dalam mengembangkan kemampuan siswa. Pembelajaran di kelas dengan menggunakan make a match ini dapat digunakan dalam semua mata pelajaran dan untuk semua tingkat usia anak didik.

Salah satu keunggulan metode ini adalah siswa mencari pasangan sambil belajar mengenai suatu konsep atau topik dalam suasana yang menyenangkan.

Langkah-langkah pembelajaran metode Make A Match adalah:

a. Guru menyiapkan beberapa kartu yang berisi beberapa konsep atau topik yang cocok untuk sesi review (satu sisi kartu berupa kartu soal dan sisi sebaliknya berupa kartu jawaban).

b. Setiap siswa mendapat satu buah kartu dan memikirkan jawaban atau soal dari kartu yang dipegang.

c. Siswa mencari pasangan yang mempunyai kartu yang cocok dengan kartunya (kartu soal atau kartu jawaban).

d. Siswa yang dapat mencocokkan kartunya sebelum batas waktu diberi poin.

e. Setelah satu babak kartu dikocok lagi agar tiap siswa mendapat kartu yang berbeda dari sebelumnya, demikian seterusnya.

f. Kesimpulan.

Pada aturan main di atas dapat juga dilakukan secara bervariasi, misalkan metode make a match tersebut bisa dilakukan di dalam ruangan atau di luar ruangan, sehingga siswa tidak merasa bosan dan pembelajaran kooperatif metode make a match ini akan tetap menarik minat, motivasi, dan keaktifan siswa pada mata pelajaran Matematika sehingga dapat meningkatkan hasil belajar.dimiliki serta berdiskusi terkait pembelajaran tanpa takut untuk berargumentasi. Selain itu, make a match ini akan menciptakan pembelajaran matematika yang lebih bermakna, karena cara pendidik menyajikan pembelajaran dengan cara yang berbeda dari yang biasa digunakan.

\section{METODE PENELITIAN}

Jenis penelitian yang digunakan dalam penelitian ini adalah penelitian eksperimen. Populasi dalam penelitian ini adalah siswa SD Negeri 149 Tungke Kabupaten Bone dan sampel dalam penelitian ini adalah siswa kelas V Tahun Ajaran 2020/2021.

Penelitian menggunakan Pre Experimental Design dengan tipe One-Shot Case Study dimana peneliti hanya mengadakan treatment satu kali yang diperkirakan sudah mempunyai pengaruh. Kemudian diadakan post test.

Table 3.1 Desain Penelitian

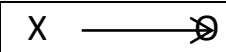

Keterangan:

$\mathrm{X}=$ Treatment atau Perlakuan

$\mathrm{O}=$ Hasil observasi sesudah treatment

\section{Prosedur Penelitian}

1. Tahap persiapan

Sebelum melakukan penelitian, peneliti terlebih dahulu melakukan persiapan sebagai berikut:

a. Menentukan sekolah untuk penelitian.

b. Meminta izin kepada kepala SD Negeri 149 Tungke Kabupaten Bone.

c. Menentukan kelas untuk melakukan eksperimen penelitian.

d. Melakukan kesepakatan dengan guru kelas tentang materi yang akan diteliti dan lamanya waktu penelitian.

e. Menyusun dan menyiapkan perangkat pembelajaran.

f. Menyusun dan menyiapkan instrumen penelitian, yaitu: tes hasil belajar dalam bentuk pilihan ganda.

2. Tahap pelaksanaan

Tahap pelaksanaan meliputi pemberian treatment yakni proses pembelajaran dengan menggunakan model pembelajaran kooperatif tipe Make a Match oleh guru.

3. Tes hasil belajar

Kelas eksperimen diberi tes pada pertemuan akhir.

4. Respons Siswa

Pada akhir pembelajaran, siswa diberi lembar angket respon siswa untuk mengetahui tanggapan/respon siswa terhadap pembelajaran. 


\section{Teknik Pengumpulan Data}

Adapun tahapan pengumpulan data yang dilakukan penulis sebagai berikut:

1. Dilakukan observasi untuk menentukan kelas yang akan dijadikan obyek penelitian serta menentukan kelas eksperimen dan kelas kontrol.

2. Siswa diberikan perlakuan, bagi kelas eksperimen diajarkan dengan model pembelajaran tipe Make A Match dan kelas kontrol diajarkan dengan metode ceramah. Karena adanya Pandemi Covid-19, maka perlakuan bagi kelas eksperimen digantikan dengan pengiriman video model pembelajaran tipe Make A Match. Peneliti membuat group pembelajaran di aplikasi WhatsApp kemudian mengunggah video ke group.

3. Siswa diberikan tes berupa pretest dan postest. Pretest digunakan untuk menentukan uji normalitas dan homogenitas soal Matematika pada kedua kelas dengan soal yang sama. Dan posttest untuk mengetahui perbedaan hasil belajar siswa yang menggunakan model pembelajaran kooperatif tipe Make a Match dan siswa yang tidak menggunakan model pembelajaran kooperatif tipe Make a Match . Tes diberikan dengan menggunakan aplikasi Google Form.

Tes digunakan untuk memperoleh data berupa nilai hasil belajar matematika setelah menggunakan model pembelajaran kooperatif tipe Make a Match pada kelas eksperimen. Indikator hasil belajar siswa disajikan dalam bentuk kategori matriks tabulasi data sebagai berikut:

Tabel 3.2 Indikator Hasil Belajar

\begin{tabular}{|c|c|c|}
\hline No & Skor & Kategori \\
\hline 1 & $90-100$ & Sangat Tinggi \\
\hline 2 & $75-89$ & Tinggi \\
\hline 3 & $55-74$ & Sedang \\
\hline 4 & $40-54$ & Rendah \\
\hline 5 & $0-39$ & Sangat Rendah \\
\hline
\end{tabular}

4. Siswa dinilai dari hasil tes yang diperoleh dari kedua kelompok di atas, yaitu kelompok kelas eksperimen dan kelas kontrol terhadap hasil belajar Matematika.
5. Dokumentasi yaitu dengan mengumpulkan segala dokumen yang diperlukan seperti lembar kegiatan siswa dan gambar-gambar kegiatan selama melakukan penelitian di kelas yang menggambarkan situasi pembelajaran di kelas.

6. Siswa diberi angket untuk memperoleh data berupa respons siswa terhadap pembelajaran. Siswa memberikan respons dengan mengisi angket respons melalui aplikasi Google Form.

\section{Instrument Penelitian}

Instrumen penelitian yang digunakan adalah berupa tes obyektif dalam bentuk pilihan ganda yang terdiri dari empat opsi dan angket respons siswa. Tes yang digunakan dalam penelitian perlu dilakukan uji validitas agar ketetapan alat penelitian terhadap konsep yang dinilai sesuai, sehingga benar-benar menilai apa yang seharusnya dinilai.

\section{Teknik Analisis Data}

1. Uji Normalitas

Uji normalitas dilakukan untuk mengetahui apakah data yang diperoleh berdistribusi normal atau tidak. Dalam menghitung uji normalitas, penulis menggunakan SPSS dengan lilifors.

2. Uji Homogenitas

Uji homogenitas dilakukan untuk mengetahui apakah sampel mempunyai varians yang homogen atau tidak.

3. Uji Hipotesis

Teknik yang digunakan dalam penelitian ini adalah menggunakan rumus ttest untuk menguji hipotesis. Uji hipotesis ini digunakan untuk mengetahui adanya perbedaan hasil belajar Matematika siswa yang diajar dengan model pembelajaran kooperatif tipe Make a Match dengan siswa yang tidak diajarkan dengan model pembelajaran kooperatif tipe Make a Match.

\section{HASIL \& PEMBAHASAN \\ Hasil Penelitian}

Langkah awal yang dilakukan peneliti adalah melakukan validitas instrument yang terdiri dari soal tes hasil belajar (Posttest) dan angket respons siswa. Validitas yang digunakan adalah validitas isi dan validitas empirik sebelum digunakan dan dilanjutkan dengan pemberian treatment penggunakan model pembelajaran kooperatif tipe Make A Match untuk mengetahui pengaruh model pembelajaran kooperatif tipe Make A Match terhadap hasil belajar matematika siswa. 
Data yang diperoleh dan dianalisis dalam penelitian ini meliputi posstest yang diambil dari kelas VA sebagai kelas Eksperimen yang berjumlah 27 orang dan kelas VB sebagai kelas control yang berjumlah 27 orang. Hasil penelitian ini diuraikan sebagai berikut:

\section{Penyajian Data Hasil Penelitian a. Deskripsi Data}

Penelitian ini dilaksanakan dengan tujuan untuk mengetahui pengaruh model pembelajaran kooperatif Tipe Make a Match terhadap hasil belajar matematika materi pecahan kelas V SD Negeri 149 Tungke Kabupaten Bone semester ganjil tahun pelajaran 2020/2021. Penelitian ini termasuk penelitian eksperimen karena penelitian ini bertujuan untuk mengetahui hubungan sebab akibat serta beberapa perlakuan-perlakuan tertentu pada kelas eksperimen. Sedangkan pada kelas kontrol tidak diberikan perlakuan.

Data dalam penelitian ini diperoleh melalui beberapa metode, yaitu metode tes. Metode tes digunakan peneliti untuk mengetahui hasil belajar siswa pada materi pecahan siswa kelas V SD Negeri 149 Tungke Kabupaten Bone.

Berkaitan dengan metode tes, dalam penelitian ini peneliti memberikan tes pemahaman berupa 10 soal pilihan ganda mengenai pecahan kepada sampel penelitian yaitu kelas VA sebagai kelas eksperimen dan kelas VB sebagai kelas kontrol. Setelah pelaksanaan tes diketahui hasil belajar yang kemudian kita dapat mengetahui hasil belajar siswa pada pecahan. Saat pemberian tes kepada siswa, peneliti memberikan tes berupa 10 butir soal mengenai materi pecahan. Tes yang diberikan telah teruji dengan validasi oleh ahli dan validitas hitung. Selain itu soal tes juga diuji kereliabelannya. Sebelum ditentukan kelas yang akan diberikan tes yaitu kelas VA dan kelas VB terlebih dahulu kelas tersebut diuji homogenitas untuk mengetahui apakah kedua kelas tersebut homogen atau tidak, jika homogen maka kedua kelas tersebut dapat dijadikan sampel penelitian.

Berikut data Posstest kelas VA sebagai Kelas Eksperimen dan kelas VB sebagai Kelas Kontrol hasil belajar Matematika:

\subsection{Deskripsi Data Posttest}

\begin{tabular}{|c|c|}
\hline Statistik & Nilai Statistik \\
\hline
\end{tabular}

\begin{tabular}{|c|c|c|}
\hline & $\begin{array}{c}\text { Kelas } \\
\text { Eksperimen }\end{array}$ & $\begin{array}{c}\text { Kelas } \\
\text { Kontrol }\end{array}$ \\
\hline Subjek & 27 & 27 \\
\hline Mean & 85.19 & 40.37 \\
\hline Median & 80.00 & 40.00 \\
\hline Mode & 80 & 30 \\
\hline $\begin{array}{c}\text { Std. } \\
\text { Deviation }\end{array}$ & 8.932 & 9.799 \\
\hline Variance & 79.772 & 96.011 \\
\hline Range & 30 & 30 \\
\hline Minimum & 70 & 30 \\
\hline Maximum & 100 & 60 \\
\hline Sum & 2300 & 1090 \\
\hline
\end{tabular}

Berdasarkan tabel di atas, dapat dilihat bahwa standar deviasi nilai Posstest Kelas Eksperimen dan Kelas Kontrol lumayan beragam. Nilai rata-rata, nilai tengah, dan modus berada pada kategori cukup baik dengan penyebaran nlai terendah pada kelas Eksperimen 70 dengan nilai tertingginya 100 dengan rentang 30 dan Kelas Kontrol nilai terendah 30 dari nilai tertinggi 60 dengan rentang 30 .

Jika skor Posttest hasil belajar Kelas Eksperimen dan Kelas Kontrol tersebut dikelompokkan ke dalam 5 kategori, maka diperoleh daftar distribusi frekuensi dan presentase kategori hadil Posttest Kelas Eksperimen dan Kelas Kontrol pada tabel berikut:

Tabel 5.2 Distribusi Frekuensi dan

Presentase Kategori Hasil Posttest Kelas Eksperimen dan Kelas Kontrol

\begin{tabular}{|c|c|c|c|c|c|}
\hline \multirow{2}{*}{ Skor } & \multirow{2}{*}{$\begin{array}{c}\text { Katego } \\
\text { ri }\end{array}$} & \multicolumn{2}{|c|}{$\begin{array}{c}\text { Krekuensi } \\
\text { Kelas }\end{array}$} & \multicolumn{2}{c|}{$\begin{array}{c}\text { Presentase } \\
\text { Kelas }\end{array}$} \\
\cline { 3 - 6 } & Eksp & Kont & Eksp & Kont \\
\hline $\begin{array}{c}90- \\
100\end{array}$ & $\begin{array}{c}\text { Sangat } \\
\text { Tinggi }\end{array}$ & 13 & 0 & $\begin{array}{c}48.1 \\
5\end{array}$ & 0 \\
\hline $\begin{array}{c}75- \\
89\end{array}$ & $\begin{array}{c}\text { Tinggi } \\
85-\end{array}$ & 11 & 0 & $\begin{array}{c}40.7 \\
4\end{array}$ & 0 \\
\hline $\begin{array}{c}\text { Sedan } \\
\text { g }\end{array}$ & 3 & 2 & $\begin{array}{c}11.1 \\
1\end{array}$ & 7,41 \\
\hline
\end{tabular}




\begin{tabular}{|c|c|c|c|c|c|}
\hline $\begin{array}{c}40- \\
54\end{array}$ & $\begin{array}{c}\text { Renda } \\
\mathrm{h}\end{array}$ & 0 & 15 & 0 & $\begin{array}{c}55,5 \\
6\end{array}$ \\
\hline $0-39$ & $\begin{array}{c}\text { Sangat } \\
\text { Renda } \\
\mathrm{h}\end{array}$ & 0 & 10 & 0 & $\begin{array}{c}37,0 \\
3\end{array}$ \\
\hline \multicolumn{2}{|c|}{ Jumlah } & 27 & 27 & 100 & 100 \\
\hline
\end{tabular}

Berdasarkan tabel frekuensi dan presentase kategori di atas, dapat diketahui bahwa Posttest Kelas Eksperimen terdapat siswa yang berada pada kategori Sangat Tinggi, Tinggi dan Sedang namun pada Kelas Kontrol siswa berada pada kategori Sedang, Rendah dan Sangat Rendah. Jika skor Posttest Kelas Eksperimen dan Kelas Kontrol dikategorikan ke dalam 5 pengkategorian, maka daftar distribusi frekuensi dan presentase hasil Posttest Kelas Eksperimen dan Kelas Kontrol dapat digambarkan pada diagram berikut:

\section{Gambar 5.1 Pengkategorian Hasil Posttest} Kelas Eksperimen dan Kelas Kontrol

Kelas_Eksperimen

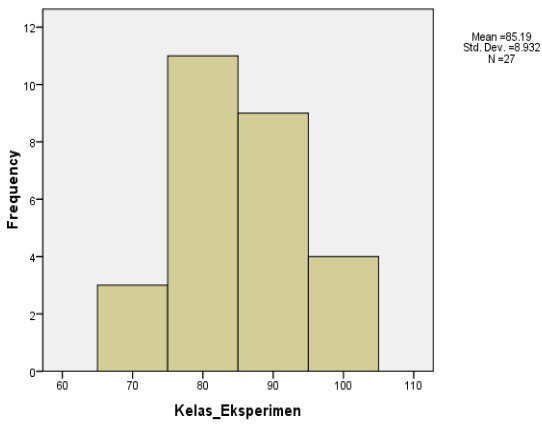

Kelas_Kontrol

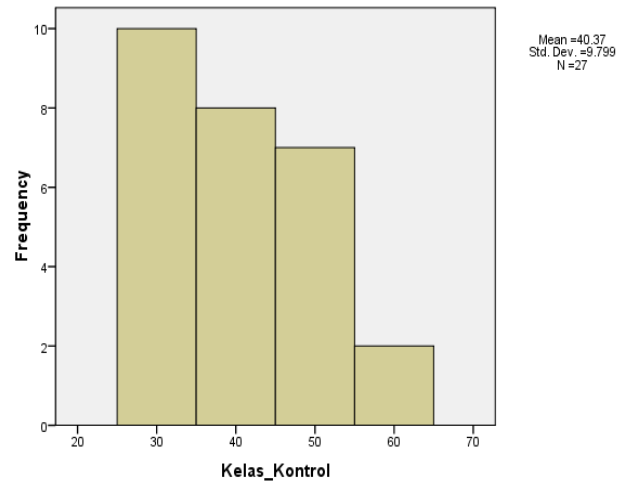

\section{b. Analisis Data Hasil Penelitian}

Setelah semua data yang diperlukan telah terkumpul peneliti melakukan beberapa uji yakni uji terhadap instrumen dan uji hipotesis. Untuk uji terhadap instrument peneliti melakukan uji validitas dan reliabilitas. Kemudian melakukan uji hipotesis yakni dengan menggunakan t-Test. sebelum melakukan $t$-Test telebih dahulu peneliti melakukan uji prasyarat yakni uji homogenitas dan uji normalitas.

\section{Uji Validitas Instrumen}

Uji Validitas ada dua cara yaitu validasi ahli dan validasi empirik. Validitas ahli divalidasi oleh dua orang yang ahli dalam bidangnya. Peneliti mempunyai 2 orang validator yakni Rahmawati Patta, S.Si.,M.Pd. sebagai validator 1 dan Fatmawati Gaffar, S.Pd.,M.Pd. sebagai validator 2. Pada validitas ahli, soal yang divalidasi dinyatakan layak untuk digunakan. Sedangka pada validitas emperik sebanyak 10 soal yang diuji cobakan kepada 10 siswa atau responden, dan dari hasil uji validitas tersebut peneliti menggunakan 10 soal yang telah diuji cobakan tersebut untuk soal test, baik kelas eksperimen maupun kelas kontrol.

Setelah divalidasi oleh validator kemudian soal yang akan diujikan kepada siswa terlebih dahulu diujikan kepada siswa yang telah mempelajari materi pecahan. . Dalam pengujian ini peneliti mengambil 10 responden sebagai sampel untuk pengujian. Setelah melakukan pengujian soal, diperoleh data hasil uji coba Posttest dan uji coba angket.

Setelah melakukan uji coba terhadap soal posttest langkah selanjutnya adalah menentukan valid atau tidaknya soal nomor 1 sampai 10. Sesuai dengan kaidah valid, soal akan dikatakan valid jika $r_{\text {hitung }}>r_{t a}$. Dengan melihat tabel apabila kita mengambil responden sebanyak 10 dengan menggunakan $a=0,05$ maka $r_{\text {tabel }}=0,632$.

Dengan menggunakan pengujian menggunakan SPSS 16.0 for windows diperoleh hasil pada Lampiran 10. Dari perhitungan SPSS diatas dapat diambil kesimpulan bahwasanya hasil dari $r_{\text {hitug }}>r_{\text {tabel, bel }}=0,632$ dengan $a=$ 0,05 . Sehingga soal nomor 1 sampai 10 valid.

\section{Uji Hipotesis}

Setelah data terkumpul selanjutnya adalah menganalisis data tersebut. Analisis data yang digunakan dalam penelitian ini adalah uji beda, yaitu dengan menggunakan Independent sample t-test. Sebelum menguji Independent sample t-test terlebih dahulu menguji prasyarat yaitu uji homogenitas dan uji normalitas.

\section{a. Uji Homogenitas Sampel Penelitian}

Uji homogenitas dimaksudkan untuk menguji apakah data dari sampel penelitian pada kelas eksperimen dan kelas kontrol mempunyai varians yang sama atau tidak. Data yang digunakan untuk menguji homogenitas kelas adalah nilai ulangan harian semester 
ganjil. Uji homogenitas untuk menentukan sampel penelitian dilakukan dengan bantuan SPSS 16.0 for windows. Suatu distribusi dikatakan homogen jika taraf signifikansinya lebih besar dari 0,05. Sedangkan jika taraf signifikansinya kurang dari 0,05 maka distribusi dikatakan tidak homogen. Data hasil uji homogenitas dapat dilihat pada tabel berikut:

Test of Homogeneity of Variances

Hasil_Belajar

\begin{tabular}{|r|r|r|r|}
\hline $\begin{array}{c}\text { Levene } \\
\text { Statistic }\end{array}$ & df1 & \multicolumn{1}{c|}{ df2 } & \multicolumn{1}{c|}{ Sig. } \\
\hline .048 & 1 & 52 & .827 \\
\hline
\end{tabular}

Berdasarkan tabel di atas diperoleh signifikansi 0,827 yang lebih besar dari 0,05. Hal ini menunjukkan bahwa sampel penelitian homogen. Jika sampel penelitian homogen maka dapat dilakukan suatu penelitian.

\section{b. Uji Normalitas Data}

Uji normalitas dimaksudkan untuk menguji apakah dalam sebuah t-test mempunyai distribusi normal atau tidak. Suatu distribusi dikatakan normal jika taraf signifikansinya lebih besar dari 0,05. Sedangkan jika taraf signifikansinya kurang dari 0,05 maka distribusi dikatakan tidak normal. Uji normalitas dilakukan sebanyak dua kali yaitu yang pertama uji normalitas data hasil angket dan yang kedua uji normalitas hasil posttest. Data tersebut dihitung menggunakan bantuan SPSS 16.0 for windows yaitu uji Kolmogorov-Smrnov.

Berdasarkan yang diperoleh dari perhitungan hasil uji Kolmogorov-Smirnov, dapat disimpulkan bahwa data rata-rata berdistribusi normal karena memiliki Asymp.Sign $\geq 0,05$. Hasil belajar kelas eksperimen memiliki Asymp.Sign 0,94 dan kelas kontrol memiliki Asymp.Sign. 0,129. ini berarti data di atas berdistribusi normal pada taraf signifikasi 0,05 .

\section{c. Uji Hipotesis}

Uji hipotesis yang digunakan dalam penelitian ini adalah uji statistic parametrik, yaitu Independent sample t-test. $\mathrm{Uji}$ ini digunakan untuk mengambil keputusan apakah hipotesis diterima atau ditolak.

$\mathrm{H}_{\mathrm{o}}=\mu_{1} \leq \mu_{2}$ tidak ada pengaruh yang signifikan model pembelajaran kooperatif tipe make a match terhadap hasil belajar matematika siswa kelas V SDN 149 Tungke Kabupaten Bone tahun ajaran 2020/2021.

$$
\mathrm{H}_{1}=\mu_{1}>\mu_{2} \text { ada pengaruh yang }
$$

signifikan model pembelajaran kooperatif tipe make a match terhadap hasil belajar matematika siswa kelas V SDN 149 Tungke Kabupaten Bone tahun ajaran 2020/2021.

Dengan dasar pengambilan keputusan sebagai berikut :

a. Jika nilai signifikansi atau Sig.(2-tailed) > 0,05 , maka $\mathrm{H}_{0}$ diterima dan $\mathrm{H}_{1}$ ditolak

b. Jika nilai signifikansi atau Sig.(2-tailed) $\leq$ 0,05 , maka $\mathrm{H}_{0}$ ditolak dan $\mathrm{H}_{1}$ diterima

c. Jika statistik $t_{\text {hitung }}<t_{\text {tabel }}$, maka terima $\mathrm{H}_{0}$ dan tolak $\mathrm{H}_{1}$

d. Jika statistik $t_{\text {hitung }} \geq t_{\text {tabel }}$, maka tolak $\mathrm{H}_{0}$ dan terima $\mathrm{H}_{1}$

Berdasarkan hasil perhitungan SPSS, diperoleh bahwa kelas control memiliki mean sebesar 40,37 dengan jumlah responden 27 orang dan kelas eksperimen memiliki mean sebesar 85,19 dengan jumlah responden 27 orang. Nilai $t_{\text {hitung }}$ diperoleh sebesar 17,564 dengan Sig.(2-tailed) 0,000. Sebelum melihat $t_{\text {tabel }}$, terlebih dahulu mencari derajat kebebasan $(\mathrm{db})$ pada keseluruhan sampel yang diteliti. $\quad d b=n-2=54-2=52$

Berdasarkan $d b=52$ pada taraf signifikansi 0,05 diperoleh $t_{\text {tabel }}=1,671$. Karena $t_{\text {hitung }} \geq t_{\text {tabel }}=17,564 \geq 1,671$ maka dapat disimpulkan bahwa terdapat pengaruh yang signifikan, adanya pengaruh tersebut juga ditunjukkan oleh Sig.(2-tailed) $=0,000 \leq$ 0,05 .

Dengan demikian dapat disimpulkan $H_{0}$ ditolak yaitu ada pengaruh model pembelajaran kooperatif tipe make a match terhadap hasil belajar matemati kelas $\mathrm{V}$ materi pecahan pada siswa kelas V SDN 149 Tungke Kabupaten Bone Tahun Ajaran 020/2021.

Berdasarkan analisis data yang dilakukan dapat diartikan adanya perbedaan antara $t_{\text {hitung }}$ dan $t_{\text {tabel }}$ sehingga sesuai dengan dasar pengambilan keputusan jika $t_{\text {hitung }} \geq t_{\text {tabel }}$ serta ditunjukkan dengan nilai signifikasi $\leq$ 0,05 maka $H_{1}$ diterima dan $H_{0}$ ditolak, yang berarti berarti dalam hal ini "Ada Pengaruh Model Pembelajaran Kooperatif Tipe Make A Match Terhadap Hasil Belajar Matematika Kelas V Materi Pecahan Pada Siswa kelas V SDN 149 Tungke Kabupaten Bone Tahun Ajaran 2020/2021". Besar pengaruh Model Pembelajaran Kooperatif Tipe Make A Match yaitu sebesar 90,55\% maka dapat disimpulkan bahwa persentase pengaruhnya tergolong tinggi.

\section{Pembahasan}

Penelitian ini bertujuan untuk mengetahui pengaruh Model Pembelajaran Koperatif Tipe Make A Match Terhadap Hasil 
Belajar Matematika siswa Kelas V SDN Mangkura V. Penelitian eksperimen dengan menggunakan Pre Experimental Design dengan tipe One-Shot Case Study.

Sampel pada penelitian ini terdiri dari du akelas yaitu Kelas Eksperimen sebanyak 27 orang dan Kelas Kontrol sebanyak 27 orang. Kelas Eksperimen merupakan kelas yang mendapatkan perlakuan berupa penggunaan Model Pembelajaran Kooperatif Tipe Make A Match.

Peneliti melakukan analisis data hasil penelitian, maka proses selanjutnya adalah mendeskripsikan hasil penelitian tersebut dalam bentuk tabel yang menggambarkan perbedaan hasil belajar matematika peserta didik pada pecahan. Hasil belajar ini dilihat dari proses pembelajaran kelas yang menggunakan Model Pembelajaran Kooperatif Tipe Make A Match pada kelas eksperimen serta metode pembelajaran konvensional pada kelas kontrol.

Berdasarkan penyajian data dan analisis data, hasilnya menunjukkan adanya perbedaan yang signifikan antara $t_{\text {hitung }}$ dan $t_{\text {tabel }}$. $t_{\text {hitung }}$ yang diperoleh dari perhitungan yaitu $t_{\text {hitung }}=17,564$, sedangkan $t_{\text {tabel }}$ pada taraf signifikasi $5 \%$ adalah 1,671. Sehingga dapat disimpulkan bahwa Model Pembelajaran Kooperatif Tipe Make A Match berpengaruh Terhadap Hasil Belajar Matematika Kelas V Materi Pecahan Pada Siswa SDN 149 Tungke Kabupaten Bone Tahun Ajaran 2020/2021

Model pembelajaran Kooperatif Tipe Make A Match terbukti dapat meningkatkan hasil belajar peserta didik, ditunjukkan oleh tabel Group Statistics dimana nilai rata-rata hasil belajar peserta didik kelompok eksperimen 85,19 sedangkan rata-rata hasil belajar siswa kelompok kontrol 40,87. Ratarata hasil belajar kelas eksperimen lebih tinggi dibandingkan kelas kontrol dapat disebabkan oleh Model pembelajaran Kooperatif Tipe Make A Match, karena siswa menjadi lebih tertarik dan dapat mempelajari konsep pembelajaran dengan menyenangkan. Sedangkan pada kelompok kontrol menggunakan pembelajaran konvensional yang tekadang membuat siswa bosan walaupun metode konvensional ini ada beberapa kelebihannya seperti guru mudah menguasai kelas, mudah dilaksanakan, dapat diikuti peserta didik dalam jumlah besar. Pada saat proses pembelajaran berlangsung kelas kontrol tidak banyak berperan aktif dalam pembelajaran. Hal ini memang pada pembelajaran metode konvensional lebih menekankan pada upaya bagaimana peserta dapat menguasai konsep melalui metode ceramah dan tanya jawab.

Hasil penelitian ini adalah pembelajaran yang menyenangkan dan bernuansa hiburan, siswa lebih aktif dan saling bekerja sama antar anggota kelompok dalam menyelesaikan masalah matematika. Untuk mencapai pembelajaran yang efektif, suasana pembelajaran perlu direncanakan dan dibangun sedemikian rupa, sehingga peserta didik mendapat kesempatan untuk berinteraksi satu sama lain. Model pembelajaran Kooperatif Tipe Make A Match memperkenalakan cara belajar yang bernuansa hiburan, menyenangkan tetapi dengan tidak meninggalkan tujuan pendidikan tersebut. Walaupun ada sedikit kendala ketika pembelajaran berlangsung namun Model pembelajaran Kooperatif Tipe Make $A$ Match telah berhasil meningkatkan hasil belajar matematika peserta didik. Sehingga dari hasil penelitian menunjukkan bahwa pembelajaran menggunakan Model pembelajaran Kooperatif Tipe Make A Match lebih baik jika dibandingkan dengan pembelajaran yang hanya menggunakan ceramah.

\section{KESIMPULAN \& SARAN}

Kesimpulan dari penelitian ini adalah:

1. Model pembelajaran kooperatif tipe make a match mempunyai pengaruh terhadap hasil belajar matematika materi pecahan siswa kelas V SDN 149 Tungke Kabupaten Bone, tahun pelajaran 2020/2021. Karena $t_{\text {hitung }}>t_{\text {tabel }}$ maka ada perbedaan antara kelas eksperimen dan kelas kontrol yaitu $17,564>1,671$.

2. Hasil perhitungan statistik menggunakan uji-t diperoleh $t_{\text {hitung }}=17,564$, sedangkan dengan $d b=52$ pada taraf signifikasi $5 \%$ di dapat $t_{\text {tabel }}=1,671$, karena $t_{\text {hitung }}>t_{\text {tabel }}$ maka ada perbedaan antara kelas eksperimen dan kelas kontrol, sehingga dapat disimpulkan ada pengaruh Model Pembelajaran Kooperatif Tipe Make A Match terhadap hasil belajar matemetika materi pecahan siswa kelas V SDN 149 Tungke kabupaten Bone tahun ajaran 2020/2021. 


\section{DAFTAR PUSTAKA}

E. Slavin, Robert. 2005. Cooperative Learning: Teori, Riset dan Praktik. Bandung: Nusa Media.

Fahrurozi, Muh. Dkk. 2016. Pengaruh Model Pembelajaran Make A Match Terhadap Aktivitas dan Hasil Belajar Siswa pada Mata Pelajaran Ekonomi. Education ; Jurnal Ilmu Kependidikan, 2(1), 139-147.

Lapono, Nabisi. Dkk. 2008. Belajar dan Pembelajaran SD. Departemen Pendidikan nasional.

Minatul Maula, Rustopo. 2012. Pengaruh Model Pembelajaran Kooperatif Tipe Make A Match Terhadap Hasil Belajar Matematika Siswa Kelas IV SD. MALIH PEDDAS; Majalah Ilmiah Pendidikan Dasar, 2(2), 36-41.

Nafisha, Vanya. Dkk. 2017. Pengaruh Model Pembelajaran Kooperatif Tipe Make A Match untuk Meningkatkan Hasil Belajar Siswa pada Materi Jenis- jenis Pekerjaan di SD. Pedadidaktika; Jurnal Ilmiah Pendidikan Dasar. 4(2), 199-207.

Nuraida dan Halid Alkaf. 2009. Metodologi Penelitian Pendidikan. Ciputat: Islamic Research Publishing.

Rusman. 2012. Model-Model Pembelajaran: Mengembangkan Profesionalisme Guru, Edisi Kedua. Jakarta: Grafindo.

Sri Windayani, Kadek. Dkk. 2017. Pengaruh Model Make A Match Terhadap Hasil Belajar Matematika Kelas IV SD. E-Journal PGSD Universitas Pendidikan Ganesha. 5(2), 1-10.

Sudjana, Nana. 2009. Penilaian Hasil Proses Belajar Mengajar. Bandung: Remaja Rosdakarya. 